\title{
Uncovering wicked problem's system structure: seeing the forest for the trees
}

\author{
Ann-Marie Kennedy, \\ Department of Marketing, Management and Entrepreneurship, School of Business and
} Economics, University of Canterbury, Christchurch, New Zealand

\section{Sommer Kapitan,}

Department of Marketing, Advertising, Retail and Sales, Auckland University of Technology, Auckland City, New Zealand

\section{Neha Bajaj,}

Department of Economics Finance and Marketing, RMIT University, Melbourne, Australia

\section{Angelina Bakonyi,}

Department of Finance, Economics and Marketing, RMIT University, Melbourne, Australia

\section{Sean Sands,}

Monash University, Clayton, Australia 
Uncovering wicked problem's system structure: Seeing the forest for the trees

\begin{abstract}
Purpose: This article uses systems thinking, systems theory, and Camillus' (2008) framework for responding to wicked problems to provide social marketers with a theoretically based framework for approaching strategy formation for wicked problems. The article treats fast fashion as an illustrative case, and takes a step back from implementation to provide a framework for analysing and gaining understanding of wicked problem system structure in order for social marketers to then plan more effective interventions. The proposed approach is intended as a theory-based tool for social marketing practitioners to uncover system structure and analyse the wicked problems they face.

Approach: Following Layton (2014), this work provides theoretically-based guidelines for analysing the black box of how to develop and refine strategy as first proposed in Camillus' (2008) framework for responding to wicked issues.

Findings: The prescription thus developed for approaching wicked problems' system structure revolves around (1) identifying the individuals, groups, or entities that make up the system involved in the wicked problem, then (2) determining which social mechanisms most clearly drive each entity and which outcomes motivate these social mechanisms, before (3) determining which role the entities play as either incumbent, challenger or governance and which social narratives drive each role's participation in the wicked problem.

Originality/value: This article shows that using systems thinking can help social marketers to gain big picture thinking and develop strategy for responding to complex issues, while considering the consequences of interventions.
\end{abstract}

\title{
Keywords: Wicked problem, systems theory, systems thinking, fast fashion, garment industry, social marketing
}




\section{Introduction}

With the rise of fast fashion and pressure on the supply chain to produce clothing faster, the two-season fashion cycle has shrunk since the 1990s from a 6-month design-to-store process to a 4-week cycle with shoddier clothing as a result (Ertekin and Atik, 2015). Inexpensive, low-quality garments are produced due to cost and time constraints on suppliers, leading to outcomes ranging from poor working conditions to low wages and environmental pollution (Adhikari and Weerantunga, 2007; Kennedy, 2015). From a consumer perspective, the fashion industry cultivates perceived obsolescence, manipulates perceptions of scarcity via drastically shortened product life cycles, and drives overconsumption and impulsivity - a fun, inexpensive shirt is as readily available and as disposable as a consumable good from the supermarket (Cline, 2013; Rivoli, 2009). International trade agreements have further driven a race to the bottom in pricing, impacting labour standards and the health of established garment manufacturing sectors. The interconnectedness of all the players make the negative outcomes of the current fashion system a wicked problem (Rittel and Weber, 1973).

Wicked problems, as formulated by Rittel and Weber (1973), are those social problems that are so complicated that it is hard to uncover a source or a clear solution. These types of problems are highly complex and include multiple stakeholders with varying values that are often contradictory. Agreement on the definition of any particular wicked problem is difficult, as is agreement on its causes and solutions. Implementation of a solution, however, tends to bring about a ripple of change through environmental factors, presenting unexpected consequences for society (Rittel and Weber, 1973; Kennedy, 2015). Such consequences and outcomes may not solve the problem, but most likely will change its nature and the efficacy of previously planned solutions. Thus, there is no stopping rule for when a wicked problem is solved, but a judgement of improvement is generally used. 
Social marketing literature on wicked problems is starting to provide theoretical approaches to solution implementation including macro-social marketing (Kennedy, 2015), behavioural ecology (May and Previte, 2016; Brennan, Previte and Fry, 2016) and variations on Rothschild's Motivation, Opportunity, Ability model (1999; Parkinson, Schuster and Russell-Bennett, 2016; Wood, 2016). These approaches share a common thread of applying systems thinking in a more holistic and long term manner. However while they provide factors for change implementation, the difficulty of problem identification and structural analysis for a wicked problem has not been addressed (Domegan et al., 2016).

This paper then, seeks to provide social marketers with a theoretically based framework for approaching wicked problems and analysing their structure, actors, and influences for effective and holistic problem identification. To do so, this work relies on systems theory and systems thinking to map out the social system surrounding and perpetuating a wicked problem. This framework allows social marketers to chart the involved stakeholders and their interactions (Layton, 2014). This paper focuses on the fast fashion industry to elucidate the issues, actors, and social mechanisms involved in creating, maintaining, and perpetuating this wicked problem. Importantly, it is not the goal of this work to demonstrate particular solutions for a wicked problem such as fast fashion, but rather to outline a theory-based approach that ensures social marketers have a guide to analysing wicked problems.

\section{Theoretical background}

\section{Wicked problems}

Wicked problems include obesity, environmental degradation, fast fashion (Camillus, 2008; Kennedy, 2015; Kennedy and Parsons, 2012; Lazarus, 2009), many aspects of health care policy and programs, and urban and regional planning (Blackman et al., 2006; Kreuter et al., 2004; Christensen 1999). 
Most social marketing problems are in fact wicked problems. However few authors have approached the topic of wicked problems in social marketing, though the literature has called for this (Dibb, 2014; Hastings, 2003; Hoek and Jones, 2001). To develop social marketing strategy and interventions, practitioners and researchers alike need to undertake pre-intervention research and environmental analysis. This is difficult for wicked problems, as they consist of a constellation of problems interacting with one another. Social marketers tend to focus on one problem alone, yet dealing with one problem in a silo from others is neither appropriate nor effective (Ackoff, 1974; Kreuter et al., 2004). Such attempts tend to lead to different results than those planned for, as they do not take into account multiple interests, priorities, stakeholder value systems, institutional complexities, or the level of uncertainty inherent in the wicked problem (Head and Alford, 2013; Kreuter et al., 2004; McGregor, 2012).

Among the sparse literature, information sharing, consultation and active participation as part of stakeholder engagement with wicked problems is advocated in French and Gordon's strategic social marketing text (2015). Kennedy and Parsons (2012) review the case of Canadian anti-smoking initiatives by discussing initiatives' contribution to change in the tobacco system, which led to smoking cessation in a large number of people. The contributions of social marketing, amongst broader system-level interventions, were identified in solving the wicked problem of tobacco control (Kennedy and Parsons, 2012).

Broadening the theoretical understanding of how social marketing at a macro level may bring about system wide change for a wicked problem, Kennedy (2015) posits that systems theory along with institutional theory can be applied. Specifically, the article theorises that for wicked problems to be addressed, institutionalised norms need to be changed through social marketing at up, mid and downstream levels simultaneously, which can be done via strategic action fields and social mechanisms (Layton, 2014). Also taking a systems view, Brennan et al. (2016) use the behavioural 
ecological model as a theory base. This model has four levels including the macro, exo, meso and micro levels (Hovell et al., 2002). The researchers apply a case study on alcohol sales and consumption and posit that the first step in analysis of wicked problems is understanding all actors in the environment and their drivers, a view that is repeated by other social marketers (e.g. Sauders et al., 2015; May and Previte, 2016; Andreasen, 2006; Parkinson et al., 2016). These influences need to be identified and mapped so that the structure of the system that perpetuates the problem can be understood, along with the interplay between actors at multiple levels simultaneously (Brennan et al., 2016; Kennedy, 2015; House et al., 1995).

The current approaches to wicked problems in social marketing use systems as their basis (e.g., macro social marketing and the ecological view). While one might argue each has a slightly different view of systems (Brennan et al., 2016), there is intuitive agreement regarding the difficulty that social marketers have with uncovering causation surrounding social problems (Domegan et al., 2016). This stems from the interconnecting web of social relationships that create and maintain a system. These social mechanisms (Layton, 2014) work holistically to cause and perpetuate each specific individual (micro), organisational/community (meso), and government or societal (macro) behaviour, and this requires combined up, mid and downstream interventions (Kennedy, 2015). Each level is connected, and so must be addressed concurrently.

Others also appeal for social marketing to be placed within its system of change instead of within individual behaviours (Fry, 2014; Tapp and Spotswood, 2013; McHugh and Domegan, 2013). Specifically

“... a holistic approach to social marketing acknowledges that stakeholders across the full ecosystem of society must be coordinated and integrated in the societal change process including legislators, business, media, other organisation and the community as an entity itself (Andreasen, 2006)" (May and Previte, 2016: p 260). 
Lefebvre (2011) acknowledges that behaviours that social marketers address take place within a multitude of influences, a system and social network. The complex behaviours within the fashion system are an example of behaviours influenced by a large number of social and cultural facets of a system (Dibb, 2014; Evans and Hastings, 2008; Lefebvre, 2013). There are multiple socio-cultural models that can be used to address these multitude of facets within wicked problems (Brennan et al., 2014), however it is generally held that they are complementary (May and Previte, 2016). Further, acknowledgement that structures within the environment/system influence each other is not new (Dresler-Hawke and Veer, 2006). Yet a way to analyse the structure of a wicked problem holistically has not been enumerated upon. Complex behaviours (e.g., buying cheap clothing, low cost/price retailer strategy) are part and parcel of complex issues (fast fashion) and it is this complexity the present research addresses.

As called for by Parkinson et al. (2016), we present an approach for prying apart the web of perpetuating factors for complex issues such as wicked problems in order to identify the structure of the problem and aid in problem identification. This article takes a step back from problem solutions to problem identification through understanding of system structure. This system structure is uncovered through analysis of interconnected networks and their governance and interactions and it is in understanding these that specific problem identification and then social marketing strategy can be formed more successfully (Domegan et al., 2016; Layton, 2014; French and Gordon, 2015; McHugh and Domegan, 2015; Brennan et al., 2016).

As yet, the social marketing literature has not provided an approach for social marketers to use to assess wicked problems in order to plan strategically for their improvement. Systems thinking can thus be used to gain a shared understanding of a wicked problem and decrease ambiguities surrounding it (Goodman, 1974). It also provides a more holistic view of the contextual and interrelated perpetuating factors, 
multiple viewpoints, and the complex nature of solution implementation and its outcomes (Batie, 2008; Head and Alford, 2013; Kreuter et al., 2004).

Therefore, this article sets out to use systems thinking and systems theory (Layton, 2014), and Camillus' (2008) framework for responding to wicked problems to provide social marketers with a theoretically based framework for approaching strategy formation for wicked problems. This work first explores Camillus' (2008) framework for taming a wicked problem, and examines the parts of a system, its structure and functions before using systems thinking (Layton, 2014) to analyse and understand the rich, multifaceted issues facing the fashion industry in the context of the wicked problem of fast fashion. The use of such an example of a wicked problem answers calls for social marketers to broaden current agendas and contexts (Dibb, 2014; Kennedy, 2015). The proposed approach is intended as a theory-based tool for social marketing practitioners to analyse and understand the structure of the wicked problems they face.

\section{Framework for responding to wicked problems}

Trying to tame a wicked problem can be approached first by gaining a consensus definition. Stakeholder involvement that forms such a shared narrative for the problem and joint commitment to action are key to approaching wicked problems (Conklin, 2006; Kreuter et al., 2004; Sabatier 1988). Traditional linear thinking which focuses on causal chains is not appropriate, as such thinking is unable to effectively address such complexities (Camillus, 2008; Head and Alford, 2013; Kreuter et al., 2004). Specific approaches include Camillus' (2008) framework, which is based on a case analysis of PPG Industries but is not theoretically grounded (see Figure 1). While this framework is useful, it is based on a goal of implementing business strategy and does not essentially differ from many other strategy formation frameworks. Camillus' (2008) overall processes for refinement and continual evaluation of the ever-changing environment 
around a wicked problem, however, should prove a key resource for social marketers once a solution or strategy is implemented.

\section{[Insert Figure 1 here]}

Key to this framework (see Figure 1), Camillus positions strategy development at the centre of stakeholder values articulation and identification, to which strategists should apply Pareto analysis on the number of possible strategies- or estimate and weigh the benefits possible and select the actions that deliver the most effective benefits to the greatest number of stakeholders- before analysing scenarios that would result from each action taken. Camillus proposes constantly scanning the environment around a wicked problem, including any cost-benefit comparisons in Pareto analysis and resulting scenario auditing, to feedback into strategic response development. Importantly, research referencing Camillus (2008) tends to focus less on implementing the framework, instead drawing upon the framework to discuss the wicked policy problems that strategists face and reflecting on how wicked issues "cannot be resolved by traditional processes of analysing vast amounts of data," (Mertens, 2015: p 3).

Camillus' framework emerges as an important tool for social marketers grappling with interventions for large-scale, many-layered wicked problems. Yet the present work suggests that 'identifying stakeholders' values, competencies, and aspirations' (the top middle box of Figure 1) is a theoretically grounded concept that is best explored through systems theory. The present research proposes that strategic social marketers use Camillus' (2008) overarching framework as a guide when considering the systems that create the wicked problem to lock horns with the stakeholders, social mechanisms, and shared narratives to audit the elements underpinning the problem (Layton, 2014).

\section{Wicked Problems as Systems}


Systems can be used to see where a wicked problem fits within a broader domain of issues (Fisk, 1982), which is key to Camillus' (2008) contention that strategists must continually scan the environment supporting a wicked issue. Society is a set of systems - social and cultural systems as well as the material environmentresponding to these problems. The cultural system includes the values, norms, and rules of society that define and police appropriate relations and interactions (Parsons and Shils, 1951). Each social system is a collection of the interactions, relationships, inputs and outputs between its members and other social systems. Patterns of behaviour are institutionalised as the chain of social exchanges becomes longer and more complex (Dixon, 1984) - building the potential for wicked problems. To study a system that created a wicked problem, one must first identify the entities participating in it, which could be individuals, organisations, groups, or networks, depending on the level of aggregation the researcher chooses to consider. The explicit boundaries of a system are fuzzy, but description of its environmental and structural dynamics is possible (Layton, 2007).

Marketing systems and social marketing systems are sub systems of the economic system (a social system). The primary purpose of marketing systems is 'the creation and delivery to customers of assortments of goods, services, experiences and ideas,' (Layton, 2014: p 4). Multiple marketing systems are linked through their inputs and outputs within the overall economic system and the material environment, and key to understanding a system is understanding the importance of those inputs and outputs (Dixon, 1984).

To understand a wicked problem, the system of which it is a part and its adjacent systems need to be mapped. Layton and Grossbart (2006) outline the parts of a system that help in understanding wicked problems. Each specific system's parts will differ, so it is important to first identify the individuals, groups or entities which make up the system, or whatever level of aggregation a social marketing activity is examining. 
Such a consideration of the aggregation or disaggregation needed for a particular wicked problem strategy is necessary to ensure correct policy and strategy management. Once the focal system's stakeholders are described, social mechanisms, critical action fields, and shared narratives are considered so that the structures, functions, and outcomes of a system can be understood (Layton, 2014).

Micro, meso and macro interactions within and between systems that go beyond one time, place, and product help to uncover interactions, motivations, influences, and value propositions (Normann, 2001). What follows next is a discussion of how to map out a system surrounding and perpetuating a wicked problem, along with the functions and interactions which perpetuate it. Identifying each entity within a focal system and which group they belong to can help to uncover and form a shared narrative regarding a wicked problem. The accompanying shared narrative and system structure provide social marketers with a means of identifying specific problems to address and form long-term, macro-level strategy for multi-level intervention-based change. To aid in reader understanding this theoretical discussion is accompanied with exemplars from the fashion industry, which has been identified as a wicked problem (Kennedy, 2015). The analyses of the wicked problem in the fashion industry begins by exploring the entities involved and the social mechanisms (Layton, 2014) that have encouraged and perpetuated the growth of the problem, then next considers shared narratives among stakeholders that offer room for social marketing intervention.

\section{Mapping the system surrounding a wicked problem}

Fast fashion entities: consumers, businesses, governments

As changes in consumer culture and industrial technologies emerged post-World War II in developed markets in the West, culturally acquired beliefs around the consumption of durable goods began to change, evoking new behaviours among the consumer class as both disposable income and the amount and variety of consumer 
goods rose. U.S. shoppers buy an average of 64 items of clothing each year, which amounts to more than 1 apparel item purchased each week (Cline, 2013). That number doubled from 1991 to 2011, showing just how sharply the rise of fast fashion and outsourcing to fast-producing, international markets impacted the biggest consumer market on the planet (Cline, 2013).

For consumers, the outcomes gained from participating in the fashion system reinforce behaviours and practices that motivate demand for cheap, new styles. Shared micro-level social mechanisms, chief among them diffused beliefs, behaviours, and values including the collective use of social signalling via clothing (Layton, 2014), have fuelled the acceleration of the fashion industry from 2 to 4 seasons per year to twiceweekly deliveries of new styles at retailers such as Zara and Mango (Cline, 2013; Rivoli, 2009). Consumers at the micro-level, thus, form the demand and driving force behind the rapidly changing fashion marketing system.

Government and business entities also colluded to help birth the fast fashion industry. Trade barriers and the quota systems under the Multi-Fiber Arrangement among 30 countries (1974-1995) functionally protected the economies of developing countries by limiting competition for textile and clothing trade. As new technology advanced the timeline of fashion production from design to storefront, the relaxation of trade restrictions began phasing out international fabric and garment manufacturing sourcing quotas in 1995. Retailers and their supply chain partners ramped up production of clothing as a result, driven to ever cheaper international source countries as textile and apparel quotas were removed almost entirely among 161 World Trade Organization countries in 2005 to record making profits (Rivoli, 2009). The Uruguay Round Agreement on Textiles and Clothing determined that import quotas be eliminated between 1995 and 2005. U.S. and E.U. politicians, responding to lobbying from groups of retailers including Wal-Mart, JCPenny, Sears and Target, spearheaded the repeal of the quota system, essentially declaring free trade after generations of trade 
barriers on textiles that had allowed developing countries' manufacturing systems to flourish.

The strategic sourcing and globe-hopping of apparel companies and retailers since 2005 has resulted in crushing competition among manufacturers and a race to the bottom as retailers seek to procure the lowest prices. Outcomes of these interactions have a human cost that goes deeper than the benefits of cheaper fashions for developedworld consumers: Overworked, underpaid, and marginalized workers; the loss of up to 30 million jobs in the developing world's textile manufacturing sector (Rivoli, 2009); and the loss of life of workers as manufactures sidestep safer practices and building maintenance to produce more garment and textile output at an even faster rate to satisfy business demand.

\section{Social mechanisms fuel the problem}

Social mechanisms, which can co-evolve or be cooperative in nature, are processes that can be used to both drive and create change in the system that has nurtured a wicked problem (Layton, 2014). Key for social marketers diagnosing a problem and its root causes is an ability to consider the patterns of interactions between entities and the outcomes those interactions consistently gain (Hedström, 2005).

Much of the social mechanisms that function to describe the way consumers interact with each other, suppliers and retailers and with governments in the fashion system centre around co-evolution processes that include the diffusion of beliefs, behaviours, and practices in the social network (Layton, 2014).

\section{Consumers}

The most fast-paced consumers of garments and apparel are early fashion innovators who are more influenced by fashion media, shop for and buy fashion more frequently, and spend more on fashion (Birtwistle and Moore, 2006). Fashion 
innovators who browse and shop stores such as H\&M and Zara 2-3 times a week report only using clothing for social occasions a few times before disposal (Birtwistle and Moore, 2006, 2007). Important to the shift in practices that fuel a faster paced consumption of clothing, consumers motivated by counter conformity can feel threatened when they perceive themselves as 'too similar' to others, and use products to display their difference (Berger and Heath, 2007; Snyder and Fromkin, 1977; Tian, Bearden and Hunter, 2001). This means the fashion industry can and does market to a desire to be different than others. Yet this also speeds up the cycle, as the more a fashion style is positioned as enhancing uniqueness, the more popular it becomes. As popularity builds, consumers who seek differentiation via their material consumption objects dispose of artefacts of the now-popular style and gravitate to the next style (i.e., Arsel and Thompson, 2011), further fuelling fast fashion.

The fashion industry benefits from the automatic, ingrained preference of consumers for new (vs. old; Greenwald et al., 1998) products. It is not only fashion innovators who consume inexpensive, readily available fashions. Unplanned purchase behaviour is more likely for any hedonic purchases, such as a new pair of jeans, made to increase pleasure (vs. utilitarian, functional products; Davies et al., 2012). This is telling as firms began to design durable products to become obsolete (Guiltinan, 2009). The result is a system that began engineering product obsolescence via limiting functional life of offerings (i.e., looser stitching and lower quality materials in clothing), designing items that prove difficult or costly to repair, and spurring consumers' psychological perceptions of obsolescence with design aesthetics (new colours and styles) that lead to reduced satisfaction and spur voluntary replacement.

As a result, consumers desire new things the more rapidly new things are produced; they become more excited about and interested in a decision to upgrade and thus, more motivated to act (Winer, 1997; Guiltnan, 2009). Consumers have thus shifted 
values from Depression-era thrift and saving to come to value 'purchases made in the near term more than the savings from delayed purchase' (Winer, 1997: p. 112).

Price pressure and the race to the bottom in the garment industry (Rivoli, 2009) also signal a cultural shift in consumer willingness to pay for fashion. American consumers spend less than 3\% of their annual household budget on apparel, yet are buying more items of clothing than they ever have (Perry, 2010). The deal-driven culture of basement and clearance sales (Lazear, 1986; Pashigian, 1988) means that most consumers in industrialized countries have a set of reference prices for fashion that are far lower than the actual economic outlay and costs. Consumers who pride themselves on thrift see cheap fashion as a badge of honour (Cline, 2013). As a result, low prices have become expected in fashion. Fashion outlet advertisements have evolved over time from style ads to sale and deal ads, further facilitating the consumer shift in perspective from consuming quality fashions to the expectation of getting 'a fashion steal' or deal on fashion.

But consumers cannot and do not alone behave to sustain fast fashion practices.

\section{Retailers and suppliers}

Asian suppliers have quickly adapted their capabilities to serve fast-fashion retail buyers, including reducing minimum-run requirements. These suppliers have also lowered the cost of goods, thus putting intense pressure on regional manufacturers (Gereffi and Frederick, 2010). This is reflected in the clear globalization of the fashion industry as a whole. The majority of retailers in the U.S. fashion industry source their manufacturing from 6-20 different countries, with another quarter relying on more than 20 different countries to produce their apparel and fashion goods ( $\mathrm{Lu}, 2014$ ).

Clothing and textile industries internationally have experienced rapid growth as a result, but not without cost. The tragic factory fires in Pakistan and Bangladesh in 2012, and the Rana Plaza factory collapse in Bangladesh in 2013 that killed 1,200 
workers, were the tipping point that called world attention to the working conditions of garment workers (International Labour Organization, 2014). Retailers and suppliers in the meso-level of the wicked problem of fashion thus have a particular motive to appear ethical and environmental, the tragedies of Rana Plaza and other unsafe conditions notwithstanding. As more powerful entities in the social system, they use their communication networks to disseminate favourable information to maintain positive interactions with both consumers and regulatory bodies.

Gap Inc. developed the first Code of Vendor Conduct in 1990, which represented the foundation for promoting a responsible and ethical work environment. The code was designed to prevent conflicts of interest by employees, ensure the company's observance of laws, and fix social and environmental standards inside the supply chain (Arrigo, 2013). Gap subsequently garnered negative press due to unethical practices by manufacturers. Fashion retailers very rarely manufacture the garments that they sell, routinely sub-contracting production to manufacturers globally (Goworek, 2007). Gap conformed to this system, acting as a design and marketing operation (Iwanow et al., 2005). Despite Gap's relatively early publication of an ethical code, a documentary on the BBC (BBC Panorama, 2000) revealed that thirteen-year-old children were still making clothes for Gap in El Salvador (Pretious and Love, 2006).

As entities in the fashion industry have responded to changes in advancing technology, norms of acceptable practices have changed, yielding shifting incentives for practices that are now allowable and imposed via systematic evolution (Layton, 2014). For instance, retailers are increasingly striving to have flexibility to respond to changing consumer demands and deliver product to stores before the competition. Buying practices are now focused on tight style deadlines, flexibility, and speed of response (Guercini, 2001). Increased consumer demand for new and unique products has led to brands such as Zara having as many as 20 seasons per year (Christopher, Lowson and Peck, 2004).

Ann-Marie Kennedy, Sommer Kapitan, Neha Bajaj, Angelina Bakonyi, Sean Sands, (2017) "Uncovering wicked problem's system structure: seeing the forest for the trees", Journal of Social Marketing, Vol. 7 Issue: 1, pp.51-73, https://doi.org/10.1108/JSOCM-05-2016-0029 
Yet the largest, most influential changes in practice stem from vertical integration, in which the supply chain is owned by the retail brand. The onset of vertical integration as a retail strategy caused a shift to global supply chains by firms desiring to work with fewer, larger, and more capable suppliers located around the world-(Cachon and Swinney, 2009; Doeringer and Crean, 2006; Perry, Fernie and Wood, 2014). In the last decade without textile quotas, marketers have also began to source modular networks to reduce costs and increase flexibility.-Modular networks provide a virtual breakdown of manufacturing functions to source the least expensive producers who focus on individual elements of apparel production from spinning, weaving, and dyeing to cut-and-make assembly and packaging (Gereffi and Frederick, 2010). As the supply base for global apparel expands, so does competition among networks, namely in the developing economies which are dependent upon labour, thus further driving costs downward and production upward. The post-quota trade regime is fostering greater competition for cost savings, affecting the less developed nations which supply labour and raw materials.

The impact of downward price pressure results in cheaper materials and processing used in garment production that also has negative environmental outcomes. Effluent runoff from dyeing plants is often pumped straight into rivers, and has turned Guangdong's Pearl River in China red and indigo, for instance (Cline, 2013). To make cheaper clothing, manufacturers turn to two large bodies of man-made fabrics: (1) cellulosic fibres, such as rayon, viscose, and man-made bamboo, in which wood and cotton scraps are treated with toxic chemicals before forming strands; and (2) oil- and plastic-based fibres that are non-renewable or can take hundreds of years to biodegrade, such as polyester-viscose and wool-nylon-acetate blends. Further, the international garment industry each year can use 145 million tons of coal and 2 trillion gallons of water alone just to produce garments (Cline, 2013; Siegle, 2011). Of note, man-made, chemically processed materials are less costly for production, but are also 
less durable than natural fibres, are less likely to be donated or reused, and are less easily recycled to create new garments.

\section{Co-Operative Social Mechanisms}

Co-operation is a social mechanism which helps the members of a social system or multiple social systems to create a shared narrative around a wicked problem (Binmore, 2005; Layton, 2014). This is accomplished not only by a shared understanding and co-operating in general but also through signalling that guides cooperation (Gintis, 2009). Cooperative exchange, specialization, scale and scope, and strategic choices, as identified by Layton (2014) have further cemented the entities involved in a wicked problem into their unique roles in contributing to the problem.

Exchange. The relationships, costs and benefits of exchange can further drive the social structure of a wicked problem, and this is especially so for retailer and supplier interactions in fast fashion. As a result of increased competition and global and industry challenges, the garment industry is increasingly divided into high-end and low-end (value) production and brands. High-end production comprises factories that use better technology and more skilled workers and low-end or value production is dominated by considerable price focus and often-poor working conditions (International Labour Organization, 2014). As an intriguing consequence for consumers, options have shifted to high-dollar, high-quality luxury fashion or low-cost, good-enough quality fashions, with relatively no middle-priced and mid-level quality options available in retail outlets.

While most companies have some relationship with their final product supplier, they are often less clear about where the raw materials come from or whether the final product suppliers are contracting production out to other factories to meet time lines and narrow budgets for low-end production (Nimbalke, Mawson and Harris, 2015). The benefits of using a third party sourcing agent include scale of operations, buying power, flexibility, and the ability to spread risk among suppliers (Gereffi and Frederick, 2010). 
Specialization. Retailers and suppliers are uniquely positioned in the fashion industry to seek out and source capabilities to exploit a competitive advantage, which further fuels the complex nature of fast fashion (Layton, 2014). For multinational businesses, this often involves searching for the least expensive services and can come at the expense of fair labour standards. Young women with relatively low skills comprise a high share of employees in the clothing industry around the world, which is often one of the few accepted forms of labour for women in developing countries such as India and Bangladesh. Women represent on average 68 percent of the workforce in the clothing industry (Gereffi and Frederick, 2010). In these countries, women may be less mobile than men and unable to change jobs easily, and hence experience greater downward pressures on general working conditions and salaries. Studies have shown women's salaries in the clothing industry dropped since the Multi-Fibre Arrangement ended in 2005.

Scale and strategic choice. Scale and scope in business contribute to the economic power of retailer and supplier alike in the social system that underpins the wicked problem. Gains and inequitable outcomes result for both parties in the wicked problem of fast fashion. For instance, the lowered prices and demand for quick turnaround time has created a vast pressure to reduce the cost of goods in the garment industry. The way a retail company purchases from its subcontracted factories and suppliers in turn affects those businesses' ability to provide fair conditions to workers. The quick order turnarounds of the fast-fashion world often lead a supplier to force workers into accepting excessive overtime hours with low salaries (Goworek 2011; Guo et al., 2013, Nimbalke, Mawson and Harris , 2015). Very few of the companies assessed in the Australian fashion report 2015 guarantee a decent price to their suppliers or otherwise financially enable their suppliers to comply with code standards. And so far it cannot be determined if companies are paying legal wages at all three garment phases: cut-make-trim manufacturing, textiles production, and cotton growing and harvesting 
(Nimbalke, Mawson and Harris , 2015). Renumerations at the piece rate or by task work also lead many workers to work long hours to earn the minimum wage, which is equivalent to performing unpaid overtime work (International Labour Council, 2014).

The demand for cheap labour has increased demand for employment in the clothing industry in Bangladesh, Cambodia, India, Pakistan, and Vietnam. At the same time, Mexico, Morocco, and Sri Lanka saw a decline in their textile production, while 80 percent of jobs in the clothing industry in the U.S. were lost (Doeringer and Crean, 2006; Gereffi and Frederick, 2010).

Uncertainty reduction. The social mechanism of uncertainty reduction via norms or avoiding unsavoury details can reduce friction in economic exchange (Layton, 2014), which further facilitates the wicked problem of fast fashion. Even when a consumer might aim to consume ethically, the mental and emotional costs of processing negative ethical information (such as the use of unfair 'sweatshop' labour) can lead to wilful ignorance and motivated forgetting of ethical attributes (Erich and Irwin, 2005; Reczek et al., 2016). Even positive information concerning ethical goods may degrade perceptions of the products - goods marketed with sustainable attributes are more likely to be perceived as being weaker and more delicate (vs. non-sustainable goods, rated as stronger and more durable; Luchs et al., 2010).

In the Australian fashion report 2015, 91\% of the 216 brands examined did not know where all their raw materials, such as cotton, come from. Another 75\% didn't know the source of all their fabrics and inputs (Nimbalke, Mawson and Harris, 2015). Retailers that haven't traced their suppliers at the raw materials stage cannot actively ensure that workers are being protected from labour rights abuses and are being paid legal minimum wages, and thus avoidance of the issue further perpetuates the wicked problem.

Systems transition. Layton (2014) refers to processes of creative destruction and renewal that become apparent as systems transition in the fashion system as apparel 
brands continuously seek to source supply chain components from the least expensive countries. The resulting cycle is both destructive- as sourcing shifts away from manufacturing in a given country whose labour wages and associated costs have risen (such as China) - and renewing, while providing economic opportunity and growth in new countries with lower costs (such as Sri Lanka, Vietnam, and Bangladesh).

Destruction can also be creative and encourage new growth, as Layton (2014) proposes: As manufacturing of more basic apparel such as T-shirts became too costly for multinational brands to continue to source from China's Shenzen area by the early 2000s, manufacturers in the area began to shift the use of their skilled labour, purchase more specialized machinery and lead manufacturing in finer apparel areas, employing better materials and more skilled stitching to manufacture higher quality goods, such as lingerie (Rivoli, 2009).

The race to the bottom in pricing, however, has placed not only manufacturers but also governments in emerging countries in competition, and puts these governments and their regulatory powers in a position to collude with manufacturers and apparel brands to keep costs low. In Bangladesh, where apparel manufacturing helped drive GDP growth an average 5\% since 1995 (Sobhan, 2012), exports doubled in the five year period from $2009-2013$ to $\$ 31$ billion, with $90 \%$ of that value in the garment industry (Bain and Avins, 2015). Bangladesh is now the second-largest exporter of garments in the world, yet the average monthly salary for Bangladeshi workers adjusted for purchasing power ( $\$ 91.45$ in 2011 dollars) is far lower than the leading exporter, China (\$324.90), and 4 other top emerging-economy producers, amounting to just $14 \%$ of a living wage for a family (Bain and Avins, 2015). The government of Bangladesh faces enormous pressure to keep wages and costs low and to avoid regulations that would produce safer working conditions, even in the face of 1,530 deaths in fashion manufacturing house fires and structural collapses in garment factories in 2012 and 2013.

Ann-Marie Kennedy, Sommer Kapitan, Neha Bajaj, Angelina Bakonyi, Sean Sands, (2017) "Uncovering wicked problem's system structure: seeing the forest for the trees", Journal of Social Marketing, Vol. 7 Issue: 1, pp.51-73, https://doi.org/10.1108/JSOCM-05-2016-0029 
Understanding the social mechanisms that drive each set of entities (Layton, 2014) and underpin the system should yield the first set of insights for a social marketer seeking to develop strategy for a change event in a wicked problem. A better understanding of who the entities are and their motivations to behave as they do, how they interact with one another, and the outcomes of these interactions in the social system is the first step for social marketers analysing a wicked problem. In the next step, this paper advances the analysis of the wicked problem of fast fashion by categorizing entities in the fashion system by their roles and action fields, and identifying their shared narratives.

\section{Action fields and shared narratives}

Incumbents. In any social system, incumbents (Layton, 2014) are any entities that benefit from the current arrangement of a system. Incumbents both dominate in the system and might seek to preserve the system as-is to ensure they continue to benefit. The ultimate aim of an incumbent is to achieve stability in the system, to maintain its current structure and to increase economic investment to continue to nourish the system.

In the fast fashion system, incumbents include most retailers, suppliers, and most Western, developed-economy consumers.

\section{Shared narratives for consumers:}

- Consumers are constantly in search of clothing 'steals' and deals. Low prices are expected in fashion.

- New clothes are experienced as part of a makeover and image overhaul. Clothing shows status, projects image, and keeps consumers feeling current and relevant.

- Having a dream closet and pursuing an apparel collection showcasing a consumer's style is a top priority. Apparel purchases are achievable for most 
consumers, even if other consumer items (from housing to cars and vacations) are less affordable and therefore out of reach.

Shared narratives for retailers and suppliers:

- Retail brands have to hop the globe in search of the cheapest suppliers to deliver the lowest prices for consumers, and typically source from as many as 20 countries (Lu, 2014). This impacts the quality of materials used to manufacture clothing, as well as labour wage costs.

- Looking green or sustainable and appearing responsible for labour standards is important for retailers and suppliers. Actually enacting Codes of Conduct for labour or sustainable practices may be lower in a retailer's priority list.

- Retailers now practice vertical integration and source modular networks of suppliers. Modular networks break down manufacturing functions into elements of apparel production from spinning and dyeing, to cut-and-make and packaging. Lower costs are passed on to consumers (and also experienced as wage pressure for suppliers).

Challengers. In the described system of a wicked problem, challengers are those who benefit less form the current structure and functioning of a system (Layton, 2014). They might seek to create instability in the system to effect change that will yield further benefits. In essence, those entities, units, groups or individuals who are disadvantaged or marginalized in the current structure can become challengers. Under the burden of a multi-faceted, ever-changing wicked problem, these challengers might not have the ability to raise a noticeable or effective challenge, or might not recognize how or when they can seek to alter the system's structure to gain more advantages.

In the fast fashion system, challengers include the labourers and workers of the textile and apparel industry, some retailers (i.e., Patagonia, the People Tree, Fruit of the Loom, Not Just a Label, Everlane) and suppliers (traceable clothiers such as Rapanui and 
designer Laura Siegel) and some consumers, such as those who practice ethical fashion or consumers in the developing world.

Shared narratives for labourers:

- Jobs need to be safer. Investment, job opportunities, and skills fashion retailers bring to countries can be hugely beneficial. But without adequate safeguards, workers can be exploited and lives can be lost. Labourers have to work in overcrowded, poorly ventilated spaces with virtually no breaks (Nimbalke, Mawson and Harris, 2015).

- Labourers seek fair employment. Though ethical sourcing policies require the payment of a legal minimum wage, the minimum wage often is not sufficient for workers and their dependents to meet basic living needs. Workers also have to work very long hours to earn even the legal minimum wage (International Labour Organization, 2014; Nimbalke, Mawson and Harris, 2015).

Shared narratives for ethical consumers:

- Pay it forward: Ethical consumers seek to pay more for local artisan work, for organics, and for ethically sourced goods made with the environment in mind.

- Ethical consumers agitate to change the system, to make others aware of fast fashion impacts on labourers and the environment.

Shared narratives for anti-fast fashion retailers:

- Do no harm, or do as little harm as possible in sourcing, processing, manufacturing, energy use, and transport. Sacrifice of profit in exchange for good outcomes for labour, environment.

- Be transparent and show your working: Tap into people's curiosity and present a behind-the-scenes look at the operation. Show the supply chain from planting the seed, to processing the fabric, energy use, and transport. 
- Simplify: Too much choice can overwhelm. Narrower clothing lines and fewer selections maximise these retailers' ability to create, market, and sell ethical apparel.

Governance units. In a social exchange system, governance units are the entities that respond to both incumbents and challengers. These governing bodies are the ultimate force responsible for maintaining the status quo or regulating change. In the fast fashion system, the primary governance units include the World Trade Organization, the U.S. government, the European Union, Trans-Pacific Partnership, fashion industry lobbying groups, and the governments of emerging countries.

Shared narratives for trade organizations:

- Eliminating 'red tape' protectionism via trade barriers lowers costs associated with trade policies and regulations, and gives retail and apparel brands more ability to respond to consumer demands.

- Supporting and including labour standards in any future trade agreements is key to social corporate responsibility efforts.

- Trade groups continue to seek ways to avoid rising costs of production and sourcing for the fashion industry's retail brands, and find outlets aside from China to diversify the apparel manufacturing base (Lu, 2014).

Shared narratives for governments:

- The largest countries for consumers of apparel seek to help business secure the lowest costs for their consumer-citizens in order to continue economic growth.

- The garment industry brings emerging countries jobs, GDP growth, and a chance to compete on the international stage. There is little incentive to regulate manufacturing to secure more fair labour standards or safer working conditions if regulations that cost money to implement will raise costs and impact the country's ability to attract apparel brand business. 
Stakeholder power balance. The discussion of the critical action fields and shared narratives that sustain the wicked problem of fast fashion would not be complete without considering the power of each of these stakeholders and how that manipulates the efficacy of their actions. As it stands, incumbents in the fast fashion situation are more powerful than the challengers (see Figure 2). Multinational retailers have more power than their suppliers and are able to dictate cost requirements and timeframes. Even anti-fast fashion retailers could be seen as having more power than suppliers, however it could be argued that there are too few of them at present to effect a difference. Labourers come last in terms of power with practically none. They are at the mercy of suppliers and as outlined here, suffer due to this.

\section{[Insert Figure 2 here]}

The place of consumers within this power discussion is more complex. Consumer sovereignty has been argued to be a farce (Kennedy and Laczniak, 2015). Instead, marketers lead consumers through setting fashions and trends and matching those to different lifestyles, which are advertised as appropriate and aspirational. Thus, while consumers assume democracy and freedom of choice to express themselves through their clothing choices, this may not be so. Therefore consumers have been left out of Figure 2, as their level of power is transient and unclear.

While governance units respond to incumbents and challengers, the power of the stakeholders and the underlying narrative of the governance units effects their response. As shown in Figure 3, this can be represented as a balancing act, with challengers and their shared narratives - fair costs and prices with ethical, sustainable production and transparency - emerging in the balance as being weaker than the incumbents and their shared narratives. This is especially so because the underlying narrative of the governance units are economic development and growth. Challengers could become more successful in changing the fast fashion system through one of two 
ways: 1) with more support, challengers could become stronger and gain more power or, 2) if governance units' narratives changed to something in line with challengers' narratives, this could shift favour away from incumbents and towards challengers, tipping the weight.

\section{[Insert Figure 3 here]}

Providing structure to the system of a wicked problem by reconceptualising key entities into incumbents, challengers, and governance units gives social marketers a tool that will allow them to be better positioned to create more informed strategic options for response to wicked issues that arise. Roles and participation are based on the (dis)advantages they derive from the system. This also aids practitioners in understanding the shared narratives that drive each set of actors, narratives that a social marketer might embrace and seek to mould or change as part of strategic responses to the wicked problem at hand. Up-, mid- and down-stream interventions can be uncovered from such an analysis.

\section{Steps to analyse the structure of a wicked problem}

The preceding pages present social marketers with a game plan drawn from systems theory (i.e., Layton, 2014) to understand and detangle the complexity of a wicked problem, from (a) documenting the micro-level, meso-level, and macro-level entities and (b) their social mechanisms, interactions and outcomes, to (c) re-envisioning each entity in the focal system in their roles as incumbents, challengers, and governance units in regards to the wicked problem, and finally (d) assessing the shared narratives each role operates under regarding the wicked problem. These narratives represent the beliefs, biases, critical actions and values that underpin the system sustaining the wicked problem, and thus serve as strategic signposts for what narratives a social marketer may seek to embrace, deconstruct, or change. 
The discussion above has uncovered the structure of the wicked problem of the fashion industry and may highlight down-, mid- and up-stream areas for social marketers to focus on. For instance, social marketers could focus on consumer behaviour and provide education, promotions, and programs to help consumers understand the true cost of their fast fashion purchases - driving them towards ethical fashion. Midstream interventions at the retailer and supplier levels might not only advocate for human and labour rights among labourers, but also rise against the fast fashion and low cost/price retail strategy. Lastly, upstream social marketing towards governance units may drive legislation and regulations that uphold human and labour rights globally.

While this explanation seems simple, there are many challenges with effecting change with a wicked problem. Necessarily, many processes were simplified within this paper, such as retail and supply chain processes, legislative processes, buying processes and especially global and economic processes. Given the nature of wicked problems, this complexity stands as one of the barriers for macro-level solution identification and implementation.

Drafting a strategic response for social marketers does not end with assessing the narratives of stakeholders in a wicked problem. The journey described above allows an adept social marketer to use a theory-based method to fill in the top box of Figure 1, 'identifying stakeholders values, competencies, and aspirations.' Adopting advice from Camillus (2008), as in Figure 1, this work encourages social marketers to evaluate the appropriateness of their strategies using first their own identity and values or the values of the social effort under consideration.

Also important to attune social marketing response to wicked problems is the use of Pareto analysis (Figure 1) on the number of possible strategies under consideration, which allows social marketers to prioritize possible changes based on the potential costs and benefits that can be delivered to the most people involved in the wicked 
problem. But of chief concern is a continuous scanning of the environment for any changes to the system and stakeholder analyses, and monitoring the changes that result from the outcome of new initiatives, which will impact the social mechanisms and outcomes for each entity embroiled in a wicked problem and may impact their shared narratives. Camillus' (2008) framework, as in Figure 1, is a cautionary reminder for social marketers to implement continual vigilance in the development of the wicked problem and any actions taken to alter its course or to impact the system in which the wicked problem first took root and flourished. Enacting one social marketing strategy might, as is the nature of wicked problems, reshape the sustaining system that originated and nurtured the wicked problem (Layton, 2014), and thus shift the narratives of all involved, necessitating a restructuring of a social marketer's position and responses.

\section{Conclusion}

Systems thinking has been posited as a more holistic method for social marketers to approach complex social problems such as wicked problems that include sustainability (Conroy and Allen 2010; McKenzie-Mohr, 2011) and health promotion (Naaldenberg et al., 2009; Best, 2011), including tobacco control (Kennedy and Parsons, 2012; Gordon, 2012; Gordon and Gurieri, 2014). Researchers further suggest that all social marketing problems are in reality wicked problems when examined in their broader context. Thus, using such thinking can help social marketers to gain big picture thinking by uncovering the wicked problem's system structure. In turn social marketers can develop strategy for responding to complex issues while considering the consequences of interventions (Collins et al., 2010; Wymer, 2011; Gordon, 2012; Gurrieri et al., 2013). System structure and systems thinking can be used to more easily identify policy for upstream social marketing and as a base for action research (French and Gordon, 2015), while encouraging social marketers to consider the multiple 
contributing forces, institutions, and structures of a wicked problem at once. This allows social marketing to have a holistic understanding of a wicked problem and its contributing parts so that 'individual and collective action, stakeholder engagement, interactions, the creation of links, partnerships and networks and co-created approaches to social change' (French and Gordon, 2015: p. 188) can be used.

Previous approaches to systems and social marketing have tended to be descriptive or case based and retrospective (e.g., Kennedy and Parsons, 2012). Thus while earlier research does provide identification of a system-wide approach, it does not provide social marketers with a framework for analysing a system themselves so that they can see the complexities of a wicked problem by uncovering its structure.

Following Layton (2014), this work provides theoretically-based guidelines for analysing the black box of how to identify and articulate stakeholder values and needs in order to develop and refine strategy as first proposed in Camillus' (2008) framework for responding to wicked issues. The prescription thus developed for approaching uncovering of the system structure of wicked problems revolves around (1) identifying the individuals, groups, or entities that make up the system involved in the wicked problem, then (2) determining which social mechanisms most clearly drive each entity and which outcomes motivate these social mechanisms, before (3) determining which role the entities play as either incumbent, challenger and governance and which social narratives drive each role's participation in the wicked problem. Only with this nuanced, theory-based understanding of the contributing factors to stakeholders' values, competencies, and aspirations can social marketers then begin to develop strategy formation to ensure correct policy and strategy management. As Camillus (2008) proposes, responses to wicked issues must involve continual refinement of strategic actions, with scenario analyses and a continuous scan of the environment to ensure the outcomes derive the change social marketers seek vs. yielding unintended consequences.

Ann-Marie Kennedy, Sommer Kapitan, Neha Bajaj, Angelina Bakonyi, Sean Sands, (2017) "Uncovering wicked problem's system structure: seeing the forest for the trees", Journal of Social Marketing, Vol. 7 Issue: 1, pp.51-73, https://doi.org/10.1108/JSOCM-05-2016-0029 


\section{References}

Abernathy F., Volpe A, Weil D (2006), "The Future of the Apparel and Textile Industries: Prospects and Choices for Public and Private Sectors", Environment and Planning A, Vol. 38 No. 12, pp. 2207-2232.

Ackoff, R. L. (1974), “The systems revolution,” Long Range Planning, Vol. 7 No. 6, pp. 220.

Adhikari, R., and Weeratunge, C. (2007), "Textiles and clothing sector in South Asia: coping with post-quota challenges", Chimni, B. L., Das, S. Kelegama and M. Rahman (eds.) Multilateralism at Cross-roads: Reaffirming Development Priorities', South Asian Yearbook of Trade and Development, B.S. Delhi: Centre for Trade and Development and Wiley India.

Andreasen, A. (2006), Social Marketing in the 21st Century. Sage Publications, Newbury Park, CA.

Arrigo, E. (2013), "Corporate responsibility management in fast fashion companies: the Gap Inc. case", Journal of Fashion Marketing and Management: An International Journal, Vol. 17 No. 2, pp. 175-189.

Ann-Marie Kennedy, Sommer Kapitan, Neha Bajaj, Angelina Bakonyi, Sean Sands, (2017) "Uncovering wicked problem's system structure: seeing the forest for the trees", Journal of Social Marketing, Vol. 7 Issue: 1, pp.51-73, https://doi.org/10.1108/JSOCM-05-2016-0029 
Arsel, Z. and Thompson, C.J. (2011), "Demythologizing consumption practices: How consumers protect their field-dependent identity investments from devaluing marketplace myths", Journal of Consumer Research, Vol. 37, No. 5, pp. 791-806.

Arthur, W. Brian (2009), The Nature of Technology: What it is and How it Evolves. New York: Free Press.

Bain, M. and Avins, J. (2015), "The thing that makes Bangladesh's garment industry such a huge success also makes it deadly," Quartz, April 24. Accessed at: http://qz.com/389741/the-thing-that-makes-bangladeshs-garment-industrysuch-a-huge-success-also-makes-it-deadly/

Batie, S. S. (2008), "Wicked problems and applied economics", American Journal of Agricultural Economics, Vol. 90 No. 5, pp. 1176-1191.

Berger, J. and Heath, C. (2007), "Where consumers diverge from others: Identitysignaling and product domains", Journal of Consumer Research, Vol. 34 No. 2, pp. 121-134.

Birtwistle, G., Siddiqui, N., and Fiorito, S. S. (2003), "Quick response: Perceptions of UK fashion retailers", International Journal of Retail \& Distribution Management, Vol. 31 No. 2, pp. 118-128.

Blackman, T., Elliott, E., Greene, A., Harrington, B., Hunter, D., Marks, L., McKee, L., Williams, G. (2006), "Performance assessment and wicked problems: The case of health inequalities", Public Policy and Administration, Vol. 21 No. 2, pp. 66-80.

Bolton, L.E., Warlop, L. and Alba, J.W. (2003), “Consumer perceptions of price (un)fairness”, Journal of Consumer Research, Vol. 29 No. 4, pp. 474-491.

Brennan, L., Binney, W., Parker, L., Aleti, T. and Nguyen, D. (2014), Social Marketing and Behaviour Change: Models, Theory and Applications. Edward Elgar Publishing, Cheltenham.

Brennan, L., Previte, J. and Fry, M. (2016),"Social marketing's consumer myopia", Journal of Social Marketing, Vol. 6 Iss 3, pp. 219 - 239.

Bruce, M. and Daly, L. (2006), "Buyer behaviour for fast fashion", Journal of Fashion Marketing and Management, Vol. 10 No. 3, pp. 329-344.

Cachon, G. P. and Swinney, R. (2009). The value of fast fashion: Rapid production, enhanced design, and strategic consumer behavior. Stanford University Press.

Camillus, J. C. (2008), "Strategy as a wicked problem”, Harvard Business Review, Vol. 86 No. 5, pp. 98-106.

Chen, L., and Estreicher, S. (2011). "A new labor era: Higher costs and greater pressures", China Business Review. Accessed at: http://www.chinabusinessreview.com/a-new-labor-era-higher-costs-andgreater-pressures/ 
Chen, Y. S., and Chang, C. H. (2013), "Greenwash and green trust: The mediation effects of green consumer confusion and green perceived risk", Journal of Business Ethics, Vol 114 No. 3, pp. 489-500.

Christensen, K. S. (1999). Cities and complexity: Making intergovernmental decisions. Thousand Oaks, CA: Sage.

Christopher, M., Lowson, R., and Peck, H. (2004), "Creating agile supply chains in the fashion industry", International Journal of Retail \& Distribution Management, Vol. 32 No. 8, pp. 367-376.

Churchman, C.W. (1967). "Guest editorial: Wicked problems." B141-B142.

Cline, Elizabeth L. (2013). Overdressed: The Shockingly High Cost of Cheap Fashion. New York: Penguin.

Conklin, J. (2006), "Wicked problems and social complexity", In J. Conklin (Ed.), Dialogue mapping: Building shared understanding of wicked problems, Chichester, UK: John Wiley, pp. 3-40.

Collins, K., Tapp, A., and Pressley, A. (2010), "Social marketing and social influences: Using social ecology as a theoretical framework", Journal of Marketing Management, Vol. 26 No. 13-14, pp. 1181-1200.

Davies, I. A., Lee, Z., and Ahonkhai, I. (2012), "Do consumers care about ethical-luxury?", Journal of Business Ethics, Vol. 106, pp. 37-51.

Dibb, S. (2014), "Up, up and away: social marketing breaks free”, Journal of Marketing Management, Vol. 30 No. 11-12, pp. 1159-1185.

Dixon, D.F. (1984), "Macromarketing: a social systems perspective," Journal of Macromarketing, Vol. 4 No. 2, pp. 4-17.

Doeringer, P. and S. Crean (2006), "Can fast fashion save the US apparel industry?" Socio-Economic Review, Vol. 4 No. 3, pp. 353-377.

Domegan, C., McHugh, P., Devaney, M., Duane, S., Hogan, M., Broome, B.J., Layton, R.A., Joyce, J., Mazzonetto, M. and Piwowarczyk, J. (2016) "Systems-thinking social marketing: conceptual extensions and empirical investigations," Journal of Marketing Management, Vol. 32 No. 11-12, pp. 1123-1144.

Dresler-Hawke, E. and Veer, E. (2006), "Making healthy eating messages more effective: combining integrated marketing communication with the behaviour ecological model", International Journal of Consumer Studies, Vol. 30 No. 4, pp. 318-326.

Ehrich, K.R. and Irwin, J.R. (2005), "Willful ignorance in the request for product attribute information", Journal of Marketing Research, Vol. 42, pp. 266-277.

Ertekin, Z.O. and Atik, D. (2015), "Sustainable markets motivating factors, barriers, and remedies for mobilization of slow fashion', Journal of Macromarketing, Vol. 35 No. 1, 53-69. 
Evans, W.D. and Hastings, G. (2008), Public Health Branding: Applying Marketing for Social Change. Oxford University Press, Oxford.

Fisk, G. (1982), "Contributors' guide for choice of topics for papers," Journal of Macromarketing, Vol. 2, pp. 5-6.

French, J. and Gordon, R. (2015). Strategic Social Marketing. Sage: London.

Fry, M. (2014), "Rethinking social marketing: towards a sociality of consumption", Journal of Social Marketing, Vol. 4 No. 3, pp. 210-222.

Gereffi, G. (1999), "International trade and industrial upgrading in the apparel commodity chain", Journal of International Economics, Vol. 48 No. 1, pp. 37-70.

Gereffi, G. and S. Frederick (2010). "The global apparel value chain, trade and the crisis: challenges and opportunities for developing countries", World Bank Policy Research Working Paper Series, No. 5281.

Goodman M.R. (1974), Study Notes in Systems Dynamics. Cambridge, MA, MIT Press.

Gordon, R. (2012), "Re-thinking and re-tooling the social marketing mix", Australasian Marketing Journal, Vol. 20 No. 2, pp. 122-126.

Goworek, H. (2011). "Social and environmental sustainability in the clothing industry: a case study of a fair trade retailer", Social Responsibility Journal, Vol. 7 No. 1, pp. 7486.

Greenwald, A.G., McGhee, D.E., and Schwartz, J.L.K. (1998), "Measuring individual differences in implicit cognition: The implicit association test", Journal of Personality and Social Psychology, Vol. 74 No. 6, pp. 1464-1480.

Guercini, S. (2001), "Relation between branding and growth of the firm in new quick fashion formulas: Analysis of an Italian case," Journal of Fashion Marketing and Management: An International Journal, Vol. 5 No. 1, pp. 69-79.

Guiltinan, J. (2009), "Creative destruction and destructive creations: Environmental ethics and planned obsolescence”, Journal of Business Ethics, Vol. 89, pp. 19-28.

Guo, R., Lee, H. and Swinney, R. (2013). "The impact of supply chain structure on responsible sourcing" in Proceedings of M\&SOM Sustainable Operations SIG Conference, INSEAD, Vol. 28, Fontainebleau, France.

Guste, C. and Clark, E. (2006), "Shifting apparel landscape; top apparel-producing nations ranked by U.S. imports for the 12 months ending May 31", Women's Wear Daily, Aug. 12. Accessed online at: http://laborrights.org/in-the-news/shiftingapparel-landscape-top-apparel-producing-nations-ranked-us-imports-12-months

Hastings, G. (2003), "Relational paradigms in social marketing”, Journal of Macromarketing, Vol. 23, pp. 6-15.

Hastings, G. and Domegan, C. (2014), Social Marketing: From Tunes to Symphonies. New York: Routledge. 
Head, B. W., and Alford, J. (2015), "Wicked problems implications for public policy and management," Administration and Society, Vol. 47 No. 6), pp. 711-739.

Hoek, J. and Jones, S.C. (2011), "Regulation, public health and social marketing: a behaviour change trinity”, Journal of Social Marketing, Vol. 1 No. 1, pp. 32-44.

House, R., Rousseau, D.M. and Thomas-Hunt, M. (1995), "The meso paradigm: a framework for integration of micro and macro organizational", in Cummings, L.L. and Staw, B. (Eds), Research in Organizational Behaviour, JAI Press, Greenwich, CT, Vol. 17, pp. 71-114.

Hovell, M.F., Wahlgren, D.R. and Gehrman, C.A. (2002), "The behavioral ecological model: integrating public health and behavioral science", in DiClemente, R.J. (Ed.), Emerging Theories in Health Promotion Practice and Research: Strategies for Improving Public Health, Jossey-Bass, San-Francisco, CA, pp. 347-385.

International Labour Organization (2014), "Wages and working hours in the textiles, clothing, leather and footwear industries", Global Dialogue Forum on Wages and Working Hours in the Textiles, Clothing, Leather and Footwear Industries. Geneva, International Labout Office.

Kennedy, A. (2015), “Macro-social marketing”, Journal of Macromarketing. Published online November 23rd, available at DOI: 10.1177/0276146715617509.

Kennedy, A. and Parsons, A.G. (2012), "Macro-social marketing and social engineering: a systems approach", Journal of Social Marketing, Vol. 2 No. 1, pp. 37-51.

Kreuter, M.W., De Rosa, C., Howze, E.H., and Baldwin, G. T. (2004), “Understanding wicked problems: a key to advancing environmental health promotion", Health Education \& Behavior, Vol. 31 No. 4, pp. 441-454.

Layton, R. (2007), "Marketing systems-A core macromarketing concept", Journal of Macromarketing, Vol. 27 No. 3, pp. 227-242.

Layton, R. (2014), "Formation, growth, and adaptive change in marketing systems," Journal of Macromarketing, Vol. 35 No. 3, pp. 302-19.

Layton, R. A., and Grossbart, S. (2006), "Macromarketing: Past, present, and possible future", Journal of Macromarketing, Vol. 26 No. 2, pp. 193-213.

Lazarus, R. J. (2009), "Super wicked problems and climate change: Restraining the present to liberate the future", Cornell Law Review, Vol. 94, 1153-1233.

Lefebvre, C.R. (2011), "An integrative model for social marketing”, Journal of Social Marketing, Vol. 1 No. 1, pp. 54-72.

Lefebvre, C.R. (2013), Social Marketing and Social Change: Strategies and Tools for Improving Health, Well-Being, and the Environment. Jossey Bass, Hoboken, NJ.

Lu, Sheng. (2014). 2014 U.S. Fashion Industry Benchmarking Study. A monograph of the United States Fashion Industry Association. Retrieved from www.usfashionindustry.com. 
Luchs, M.C., Walker Naylor, R., Irwin, J.R., and Raghunathan, R. (2010), “The sustainability liability: potential negative effects of ethicality on product preference", Journal of Marketing, Vol. 74, pp. 18-31.

Marks \& Spencer (2016). "Plan A: responsible sourcing”, accessed online at: http://corporate.marksandspencer.com/plan-a/our-approach/businesswide/responsible-sourcing

May, C. and Previte, J. (2016),"Understanding the midstream environment within a social change systems continuum", Journal of Social Marketing, Vol. 6 Iss 3 pp. 258 -276 .

McHugh, P. and Domegan, C. (2013), "From reductionism to holism: how social marketing captures the bigger picture throught collaborative system indicators", in Kubacki, K. and Rundle-Thiele, S. (Eds), Contemporary Issues in Social Marketing, Cambridge Scholars Publishing, Newcastle, pp. 78-95.

McGregor, S. L. (2012), “Complexity economics, wicked problems and consumer education", International Journal of Consumer Studies, Vol. 36 No. 1, pp. 61-69.

Mertens, D.M. (2015), “Mixed methods and wicked problems," Journal of Mixed Methods Research, 9 (1), 3-6.

Nimbalke, G., Mawson, J. and Harris, C. (2015), "The Truth Behind the Barcode: the 2015 Australian Fashion Report," accessed online at https://www.baptistworldaid.org.au/assets/Be-Fair-Section/FashionReport.pdf

Normann, R. (2001), Reframing Business: When the Map Changes the Landscape. Chichester, UK: John Wiley \& Sons.

Parsons, T., and Shils, E.A. (1951), "Values, motives, and systems of action," in Parsons, T. \& Shils, E.A. (eds). Toward a General Theory of Action, Harvard Univesrity Press, pp. 247-275.

Reczek, R.W., Irwin, J.R., and Ehrich, K. R. (2016), “That's Now How I Remember It: Willfully Ignorant Memory for Ethical Product Attribute Information," manuscript in progress.

Rittel, Horst W., and Webber, Melvin M. (1973). Dilemmas in a general theory of planning. Policy sciences, 4(2), 155-169.

Rivoli, P. (2009), The Travels of a T-Shirt in the Global Economy Second Edition: An Economist Examines the Markets, Power, and Politics of World Trade, Wiley and Sons, Hoboken, NJ.

Rothschild, M. (1999), "Carrots, sticks, and promises: a conceptual framework for the management of public health and social issue behaviors", Journal of Marketing, Vol. 63 No. 4, pp. 24-37.

Parkinson, J., Schuster, L. and Russell-Bennett, R. (2016),"Insights into the complexity of behaviours: the MOAB framework", Journal of Social Marketing, Vol. 6 Iss 4, pp. $412-427$. 
Perry, M.J. (2010), "Apparel spending as a share of disposable income: Lowest in U.S. history," accessed onling at http://seekingalpha.com/article/194764-apparelspending-as-a-share-of-disposable-income-lowest-in-u-s-history.

Perry, P., Fernie, J. and Wood, S. (2014). "The international fashion supply chain and corporate social responsibility", Logistics and Retail Management, Vol. 4, pp. 7799.

Pretious, M. and M. Love (2006). "Sourcing ethics and the global market: the case of the UK retail clothing sector", International Journal of Retail \& Distribution Management, Vol. 34 No. 12, pp. 892-903.

Runciman, W. G. (2009), The Theory of Cultural and Social Selection. Cambridge, UK: Cambridge University Press.

Sabatier, P. A. (1988), "An advocacy coalition framework of policy change and the role of policy-oriented learning therein," Policy Sciences, Vol. 21 No. 2-3, pp. 129-168.

Saunders, S.G., Barrington, D.J. and Sridharan, S. (2015), "Redefining social marketing: beyond behavioural change”, Journal of Social Marketing, Vol. 5 No. 2, pp. 160-168.

Schon, D., and Rein, M. (1994). Frame Reflection: Resolving Intractable Policy Issues. New York, Basic Books.

Siegle, Lucy (2011). To Die For: Is Fashion Wearing Out The World? London: Fourth Estate.

Snyder, C.R., and Fromkin, H.L. (1977), "Abnormality as a positive characteristic: The development and validation of a scale measuring need for uniqueness", Journal of Abnormal Psychology, Vol. 86, No. 5, pp. 518-527

Sobhan, Zafar (2012), "Progress and Globalization in Bangladesh: The Tazreen Fashions Garment Factory Fire," Vice Media, Dec. 2. Accessed online at http://www.vice.com/read/progress-and-globalization-in-bangladesh-thetazreen-fashions-garment-factory-fire.

Stead, M., Gordon, R., Angus, K. and McDermott, L. (2007), "A systematic review of social marketing effectiveness," Health Education, Vol. 107 No. 2, pp. 126-91.

Tapp, A. and Spotswood, F. (2013), "From the 4Ps to COM-SM: reconfiguring the social marketing mix", Journal of Social Marketing, Vol. 3 No. 3, pp. 206-222.

Tian, K.T., Bearden, W.O. and Hunter, G.L. (2001), “Consumers' need for uniqueness: Scale development and validation", Journal of Consumer Research, Vol. 28 No. 1, pp. 50-66.

Walker, L. (2012), "Walmart accused of greenwashing," Environmental Leader, accessed online at: http://www.environmentalleader.com/2012/03/08/walmart-accusedof-greenwashing/

Weber, E., and Khademian, A. M. (2008), "Managing collaborative processes: Common practices, uncommon circumstances", Administration and Society, June 30. 
Winer, R. (1997), "Discounting and its impact on durables buying decisions", Marketing Science, Vol. 8, pp. 109-118.

Wood, M. (2016),"Midstream social marketing and the co-creation of public services", Journal of Social Marketing, Vol. 6 No. 3, pp. 277 - 293.

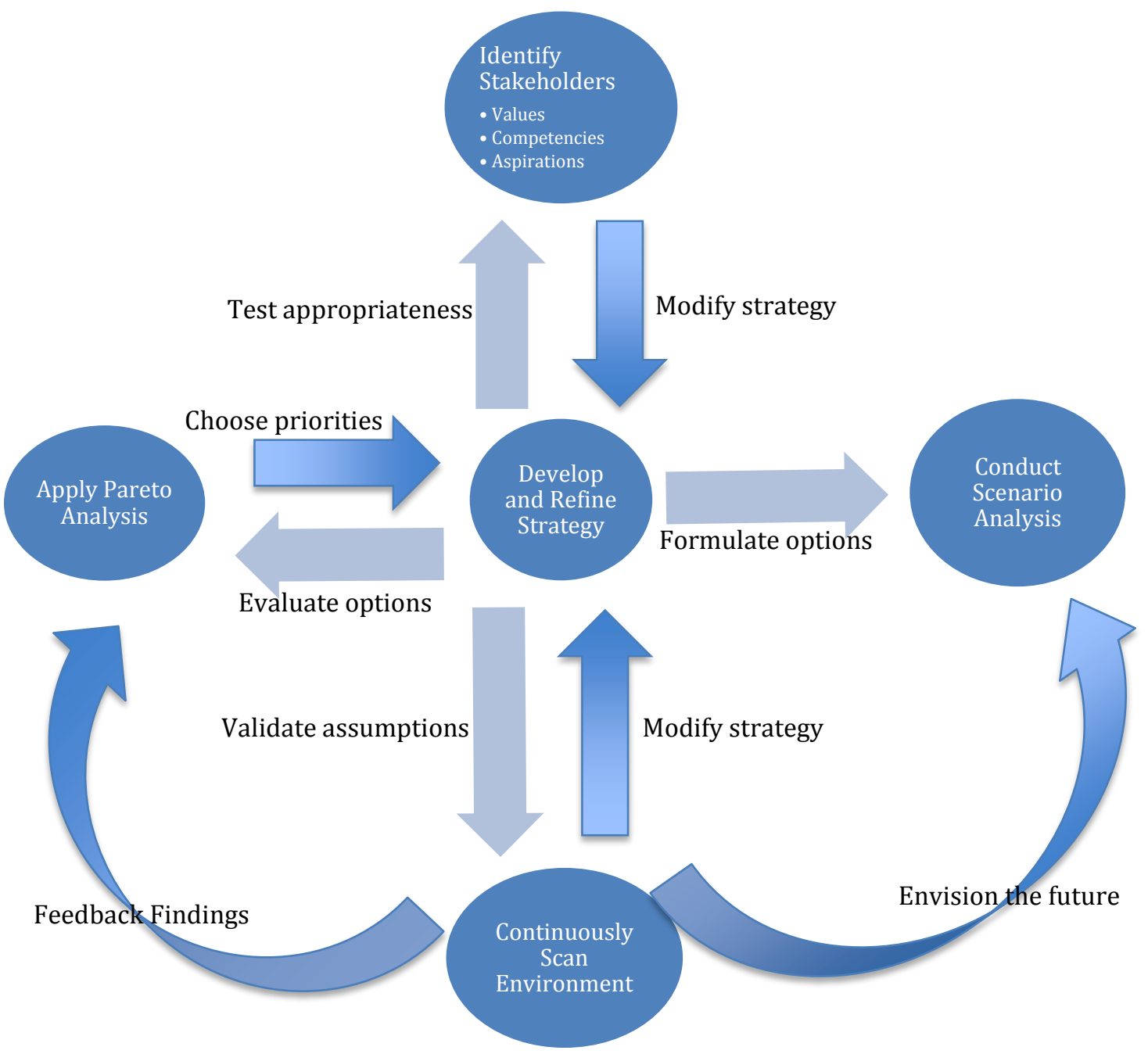

Figure 1: Framework for Responding to Wicked Problems (Camillus, 2008) 


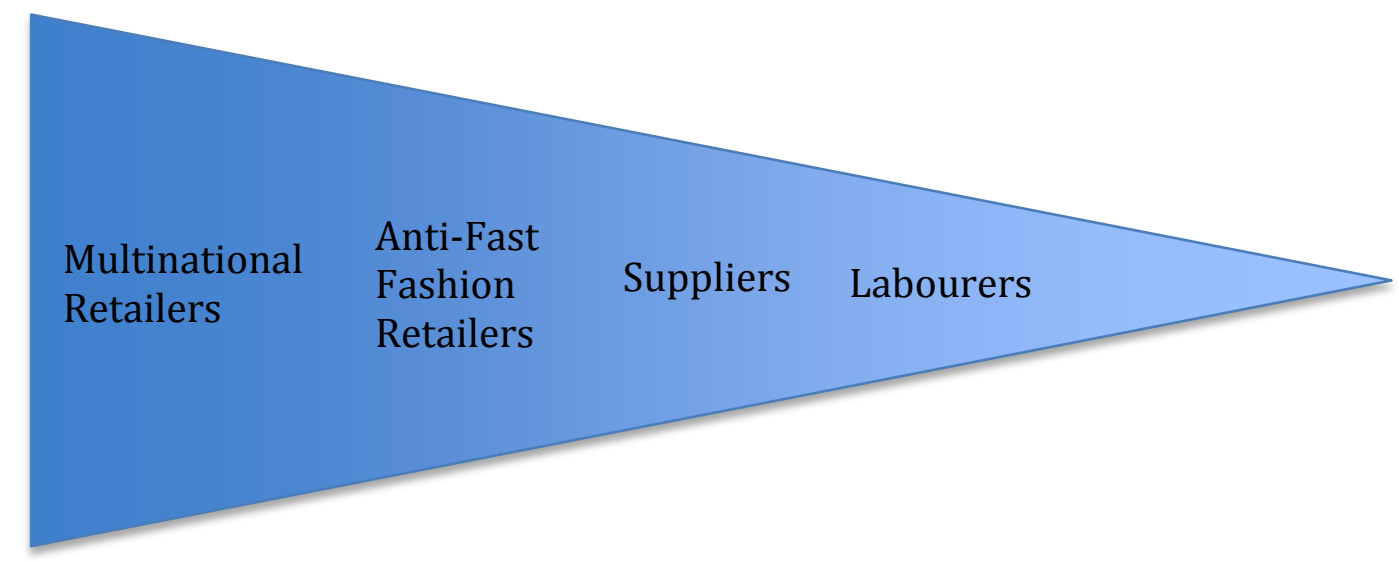

Figure 2: Relative Power of Incumbents and Challengers

\section{Challengers}

\section{Incumbents}

\section{Labourers, Ethical \\ Consumers and Anti-Fast \\ Fashion Retailers \\ - Fair costs and prices \\ - Ethical and sustainable \\ production practices. \\ - Transparency.}

\section{Consumers}

- Low prices

- Freedom of choice

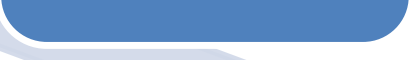

Retailers and Suppliers

- Low costs and prices

- Flexible manufaturing

- Greenwashing because of lack of

transparency

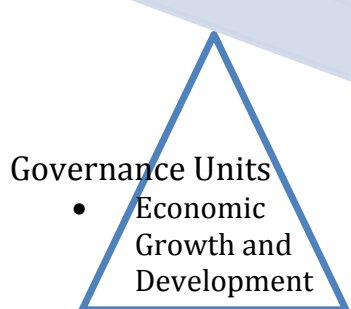

Figure 3: Balancing Act of Narratives and Power

Ann-Marie Kennedy, Sommer Kapitan, Neha Bajaj, Angelina Bakonyi, Sean Sands, (2017) "Uncovering wicked problem's system structure: seeing the forest for the trees", Journal of Social Marketing, Vol. 7 Issue: 1, pp.51-73, https://doi.org/10.1108/JSOCM-05-2016-0029 